\title{
Hospital Based Cell or Tissue Processing Facility
}

National Cancer Institute

\section{Source}

National Cancer Institute. Hospital Based Cell or Tissue Processing Facility. NCI

Thesaurus. Code C133322.

A cell or tissue processing facility that is located within a hospital. 